\title{
Toronto International Film Festival 2011
}

\author{
By Brandon Wee
}

Fall 2011 Issue of KINEMA

HIGHLIGHTS FROM THE TORONTO INTERNATIONAL FILM FESTIVAL 2011

Programming for TIFF's 36 th edition (8-18 September 2011) was suitably taut and continued its pragmatic fixation on politically dominant cinemas, but the routine also allowed some room for bold selections, notably in the inclusion of Mark Cousins' epic 15-hour documentary, The Story of Film: An Odyssey, along with Lav Diaz's challenging 6-hour drama, Century of Birthing. In its third year, the 'City to City' section looked to Buenos Aires and premiered ten new titles to highlight the vigour of contemporary Argentine cinema. And although Toronto rashly abandoned its short-lived Southeast Asian section some years ago, it was ironic that Southeast Asia enjoyed its best presence ever at the festival. For the first time by sheer coincidence, the event's extensive line-up berthed at least one representative film from (or about) the region's largest states: Indonesia, Malaysia, Myanmar, the Philippines, Thailand, and Vietnam. Ten samplings of this year's program follow:

The Artist (Michel Hazanavicius, France 2011)

A Hollywood silent movie star digs his professional grave prematurely when he turns his back on the grand arrival of motion picture sound in 1927. Meticulously attuned to the look and feel of eras past, nostalgia fanboy Michel Hazanavicius paints this comedy black-and-white and dots it with intertitles in a sentimental throwback to the Silent-Talkies transition of the 1920s. Swarthy Frenchman of the moment Jean Dujardin plays the preening actor who learns to swallow his pride with the coddling of his devoted co-star and love interest (Bérénice Bejo), loyal chauffeur (James Cromwell), and faithful Jack Russell terrier (Uggy).

The Descendants (Alexander Payne, USA 2011)

A scion of old money is about to sell a lucrative piece of Hawaiian land on behalf of his clan when a tragic turn of events involving his family conspires to influence his power as trustee of the vast estate. Adapted from Kaui Hart Hemmings' 2007 novel, Alexander Payne's latest bourgeois drama is a paint-by-numbers routine brought to life by a touching story and its exotic Polynesian setting. Not to be ignored is George Clooney's participation as the complacent lawyer, whose confessional midlife crisis about his newfound compassion for family and legacy takes all of two hours to resolve.

Good Bye (Mohammad Rasoulof, Iran 2011)

No matter how one looks at Mohammad Rasoulof's latest film, his chronicle of a persecuted lawyer who exhausts all avenues at self-exile is as good as a defensive headbutt to the country's authoritarian reality. Although a patient Noora (Leyla Zareh) manoeuvres calmly between various parties she believes can help her leave Iran, each illusory step forward routinely knocks her back to square one. Shot mostly in interiors, and in stunning depths of blue, the story's chilling effect is autobiographical by default: Iranian authorities have since imprisoned Mohammad (along with 'partner in crime' Jafar Panahi) for alleged collusion in anti-regime propaganda.

Hanaan (Ruslan Pak, South Korea 2011)

Ostensibly a tragic tale about an Uzbek narcotics cop who ironically becomes a heroin junkie, Ruslan Pak's debut feature is also notable for its cultural commentary on the marginalized Koryo-saram, the diaspora of ethnic Koreans living in Central Asia's post-Soviet states. Stanislav Tyan plays the artless officer whose scruples compel him to quit when a corrupt boss releases a homicidal dealer he personally nets from a sting. Hanaan refers to a utopian land of promise: perhaps this is the drug-induced antidote for generations of oppression, or else it is the Korean motherland, shown as a rival for deceptive salvation.

Himizu (Sono Sion, Japan 2011)

Brash and bruising, just as many of his recent films have been, Sono Sion's second film of 2011 (after the brassy Guilty of Romance) is an intense joyride of adolescent anguish brewing in a stew of hostile parenting and indifferent societal support. Charming leads Sometani Shota and Nikaido Fumi play a couple whose dysfunctional family life lead them to find mutual solace in each other's madness. In a respectful tribute to 
Japan's trauma and resilience this past year, Sono embellished Furuya Minoru's 2001 manga by changing the story's setting to an unnamed rural town trashed by a tsunami, among other things.

The Lady (Luc Besson, France-UK 2011)

Critics did not warm to Luc Besson's romance biopic of respected Myanmar activist Aung San Suu Kyi, which dramatizes events surrounding the first of her several house arrests that hastened her Nobel Prize win. But apart from a clumsy screenplay, the story still plays respectably within the genre's limits. On hindsight, only Michelle Yeoh could have portrayed Daw Suu given her beautiful likeness, but thanks to the film's structure, it is British actor David Thewlis who is given equally commanding screen time as Suu Kyi's influential late husband, Michael Aris, a role he delivers movingly - albeit at Yeoh's expense as lead.

Monsieur Lazhar (Philippe Falardeau, Canada 2011)

When an Algerian immigrant offers to replace a Montreal primary school teacher after she commits suicide, the muted trauma of the man's young charges becomes a reflection of the dire circumstances of his own escape for greener pastures. As the film's lead, the Algerian comedian Fellag is well cast as a kindly tutor whose attempts to counsel his students' bereavement is met with institutional contempt. Adapted from Québec playwright Évelyne de la Chenelière's 2002 stage monologue, Bashir Lazhar, Philippe Falardeau's clinical interpretation is by all accounts a movie for those who like their cinema served cold and morose.

Once Upon A Time In Anatolia (Nuri Bilge Ceylan, Turkey-Bosnia and Herzegovina 2011)

Few filmmakers can afford the luxury of excluding the element of suspense from plots involving a murder, but under Nuri Bilge Ceylan's tempered direction, a police case about two accused men leading investigators to damning evidence is bleached of all dramatic anticipation. With an unnamed region of Turkey's vast Anatolian plains serving as an imposing backdrop, the residual tableau details the minutiae of the probe led by various provincial officials till its conclusion at a village. Deftly composed and played without any pretensions, this is auteurist cinema in its most consummate form.

Samsara (Ron Fricke, USA 2011)

Depending on your aesthetic and political orientation, director Ron Fricke's and producer Mark Magidson's assemblage of random scenes showing humankind and the natural world is either an awesome collage that captures the diversity of existence on this planet, or an arrogant mosaic of wallpaper kitsch passing off as spiritual metaphor. Shot in 25 countries over two decades, Samsara - a Buddhist term describing the cosmic circle of life - functions at the very least as a study in visual anthropology. Taken alone, the composition and cinematography of the team's images are dramatically observed: first shot on high-resolution film, then further digitized for crisp projection.

UFO In Her Eyes (Guo Xiaolu, Germany 2011)

When a farming peasant reports separate sightings of a UFO and a mysterious foreigner in distress, the strange news soon ignites a chain reaction of hysteria and crazy ambition in her provincial village. A faceless government stooge is sent to investigate her claims, and through a series of thuggish interrogations, the lives and private thoughts of several villagers are revealed with candour - not least of plucky key witness Kwok Yun (Ke Shi) and the village's opportunistic chief (Mandy Zhang). Guo Xiaolu visualizes her eponymous 2009 novel as an absurdist allegory of China's predatory hunger for progress despite its gaping historical wounds.

\section{Author Information}

Brandon WEE lives in Toronto. He has written for Asia Pacific Arts (Los Angeles), Cineaste (New York), Cinema Scope (Toronto), Ricepaper (Vancouver), and Senses of Cinema (Melbourne). 


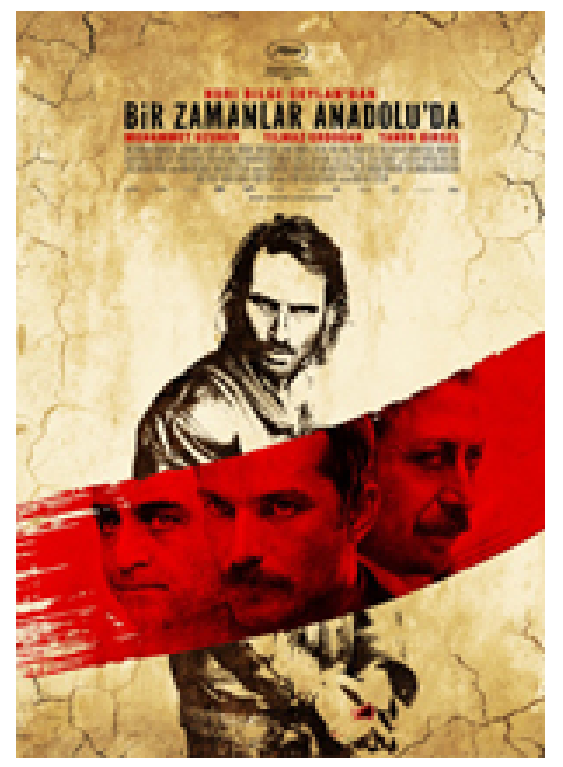

Figure 1: Once Upon a Time in Anatolia (Turkish publicity poster) 